\title{
A study of the supervision effectiveness on the registered forestry-seed commercial providers: for better seed-circulation policies
}

\author{
Tri Astuti Wisudayati ${ }^{*}$, Dede J. Sudrajat, Yulianti Bramasto, Naning Yuniarti, Kresno Agus \\ Hendarto, Dharmawati F. Djam'an, Kurniawati Purwaka Putri, Evayusvita Rustam, and \\ Desmiwati \\ Forest Tree Seed Technology Research \& Development Center (FTSTRDC); Research, Development \\ and Innovation Agency (FORDA), Ministry of Environment and Forestry; Jl. Pakuan Ciheuleut PO \\ BOX 105, 16001, Bogor, Jawa Barat, Indonesia
}

\begin{abstract}
To ensure that only high-quality seed is marketed, the seed inspector of the registered forestry-seed commercial providers plays a vital role. It will perform all the necessary tasks, including variety inspection, release testing of seed processing, and enforcement of the seed regulation. The registered forestry-seed commercial providers should conform to seed standards. Currently, the availability of high-quality seeds is crucial to achieve predictable planting. In case of unavailability of sufficient qualities standard, the seed inspector allowed for operating the punishment act. Therefore, this research aims to evaluate both the seed inspector and the registered forestry-seed commercial providers to indicate that the seedregulations implementation is successful. Data are collected by spreading questionnaire and using a narrative-based qualitative method. The result confirms that policy formulation is a challenge to the regulators, but processes effectively tackle this challenge in four sequence stages. The first stage is the problem formulation about seed-sources development, seed variety coordination at permanent nurseries, law reinforcement, and regulator role strengthening. The second stage is policy agenda through controlling over market opportunities by the regulator. The third stage is selecting alternative policies to solve problems by implementing the cluster system based on local-seed variety. The fourth stage is establishing procedures.
\end{abstract}

\section{Introduction}

The area of critical land throughout Indonesia until 2018 was estimated at 14,006,450 hectares [1]. The rate of forest degradation was estimated at \pm 1.08 million hectares per year [2]. On the other hand, vegetatively forest and land rehabilitation (RHL) to deal with these critical lands only reached 395,169 hectares in 2019 [3]. This condition requires attention to restore the function of the land by implementing seed procurement activities. Supposedly, the productivity of seeds by the forestry-seeds providers should be increased to meet the

* Corresponding author: triastutiwisudayati@gmail.com 
planting planning needs. In fact, several forestry-seeds commercial providers have complained about the shrinking market of seeds [4]. So, it has become increasingly essential for a central government role in the light of a rapidly diminishing seeds market sector besides quickly constructing a permanent nursery to ensure the availability of seeds and seedling. One of the main tasks of the local government is also to inspect these seed circulation [5]. Togetherness develops the mass and sustainably seeds source and settles the compliance of a commercial-administrative arrangement in general.

This study evaluates both the seed inspector and the registered forestry-seed commercial providers to get holistic suitable information which is can indicate the seed-regulations implementation is successful. Using a four-stage that is usually elaborate in the policy reformulating, this study raises concepts and methods for seed-circulation analysis in forestry need further development and refinement in the context of the cluster concept. Concerning the communication and cooperation along the value chain of seeds market, there is an intervention pattern between stakeholders for more holistic, standardized, replicable and comparable framework of cluster policy development based on local seed variety.

\section{Research methods}

\subsection{Study site description}

The forest sector of West Java Province is characterized by more than 49 forestry-seed commercial providers in different spatial scales. It is covering a wide range of forestry seed procurement. The case study was carried out based on a questionnaire survey among 6 forestry-seeds commercial providers, namely UD Tanjung Harapan, CV Calakan Bina Lingkungan CV Tampomas Hijau, CV Lembur Kuring, CV Agronusa Sejahtera, and CV Akor Mas. They play the leading role of seed production and seed-source utilization under the inspection of the Forest Plant Germination Center located in Jatinangor, Sumedang District, West Java Province.

\subsection{Data collection and analysis}

Data collection took place in the form of a written questionnaire, which was organized into three sections. Section one is general information (such as contact information). Within section two, questions were grouped into nine questionnaire items and mostly closed questions with four answer categories. Within the questionnaire, the respondents specify their level of agreement or disagreement on a symmetric agree-disagree scale for a series of statements [6] while responding to supervision effectiveness on the registered forestry-seed commercial providers. In addition, the last section included an open-ended question allowing for not specified input into the survey.

Interpretation results of questionnaire items can help the researcher diagnose why some items did not work well and suggest ways to improve them. This item analysis uses the policy reformulating stage (Fig. 1). Problem formulation captures the need to provide holistic supervision on how successful the evaluation assessment and if it needs to be replaced by better ones. The policy agenda is representing by value chain intervention. Selecting alternative policies is supporting by the cluster management based on local-seed variety. The establishing procedures cover aspects of improving a commercialadministrative of arrangement. 


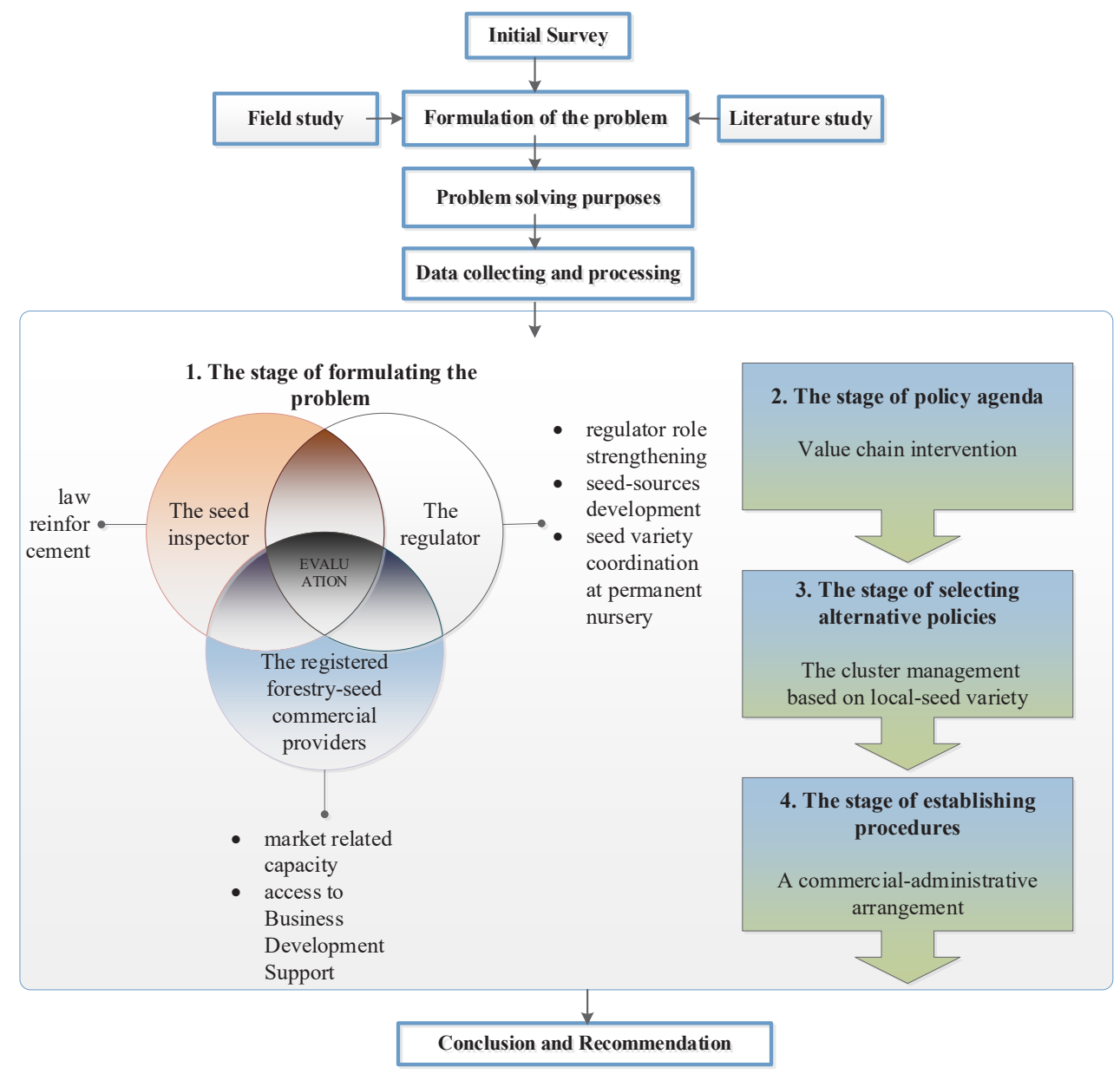

Source: Author, processed, year 2021

Fig.1. The research conceptual framework uses the policy reformulating stage

\section{Result and discussion}

\subsection{The problem formulation}

The first step for problem formulating is to be as knowledgeable as possible about the entire forestry-seed circulation. According to the current supervision evaluation, the low score of the assessment comes from the necessary measures to ensure that only high-quality seeds are marketed (Table 1). Over the implementation of the forestry seed circulation law, the regulator formed and assembled a seed inspector [7]. The seed inspector represents nearly the same structure as involved in the certification of the forestry-seed commercial providers. An additional evaluation is needs for access to seed sources and markets. The improved chain performance of the markets should become more clearly in view. It includes developing a comprehensive knowledge of the business development support and ecological dimensions. Including the relationships of the permanent nursery and forestryseed commercial providers must be interesting for coordination. With holistic supervision, this stage is the opportunity for improving the enabling environment of the policy. 
Table 1. The low score of assessment as a problem formulation

\begin{tabular}{|c|c|c|c|}
\hline No. & The statement of supervision evaluation & \multicolumn{2}{c|}{$\begin{array}{c}\text { The result of } \\
\text { low score }\end{array}$} \\
\hline 1 & $\begin{array}{c}\text { Permenhut Number: P.01/Menhut-II/2009 has accommodated the } \\
\text { interests of the forestry-seed commercial providers in the overall } \\
\text { management of forest plant seeding activities }\end{array}$ & 62,50 & Fair \\
\hline 2 & $\begin{array}{c}\text { There is no gap between the Permenhut Number: P.01/ Menhut-II / } \\
2009 \text { policy and the ideal conditions regarding the implementation of } \\
\text { forest plant seedlings. }\end{array}$ & 45,83 & Fair \\
\hline 3 & $\begin{array}{c}\text { The registered forestry-seed commercial providers can show a letter } \\
\text { from supplier as a distributor. }\end{array}$ & 62,50 & Fair \\
\hline 4 & $\begin{array}{c}\text { According to Permenhut Number: P.28 / Menhut-II / 2010, the object } \\
\text { of the seed-circulation monitoring by the seed-inspector is the } \\
\text { procurement of seeds, distribution of seeds, and distribution of seeds } \\
\text { for commercial purposes. }\end{array}$ & 62,50 & Fair \\
\hline 5 & $\begin{array}{c}\text { The seed-inspector have the right to impose sanctions or penalties on } \\
\text { the forestry-seed commercial providers if there are three or more } \\
\text { warnings for the same error related to limited access to policy, } \\
\text { scientific and technological information. }\end{array}$ & 62,50 & Fair \\
\hline
\end{tabular}

Source: Author, processed, year 2021

\subsection{The policy agenda}

After understanding the holistic supervision, the study then recognizes the policy agenda through value chain interventions. Five key development objectives of value chain interventions are increasing productivity, enhancing access to inputs, increasing access to markets, strengthening value-chain relationships, and improving the enabling environment (Figure 2). It is prioritized based on costs, time horizon, organizational capacity, and value chain actor involvement [8]. Productivity interventions can begin from production and sell seed provided such seed meets the minimum quality standards and procedures stipulated. The most feasibly and financially profitable seed source is the certified seed source [9]. Lack of economic and ecological productivity-enhancing cause an inefficient business skill of forestry seed commercial providers. Access to input can intervene by providing guidance, supervision, consultation, monitoring, evaluation, education, training, and empowerment activities. The poor relationship of the market actors causes intervention in access to the market that permits the registered forestry-seed commercial providers to have a political voice. Their political involvement supports a comprehensive information system that calculates the need for seeds in an area or nationally market. Strengthening relationship intervention is very much needed as the basis procurement for seed variety planning. Implementing cooperation patterns can limit the weaknesses of the forestry seed circulation law by addressing the enabling environment to show market actor's behavior or stakeholder's reactions. 


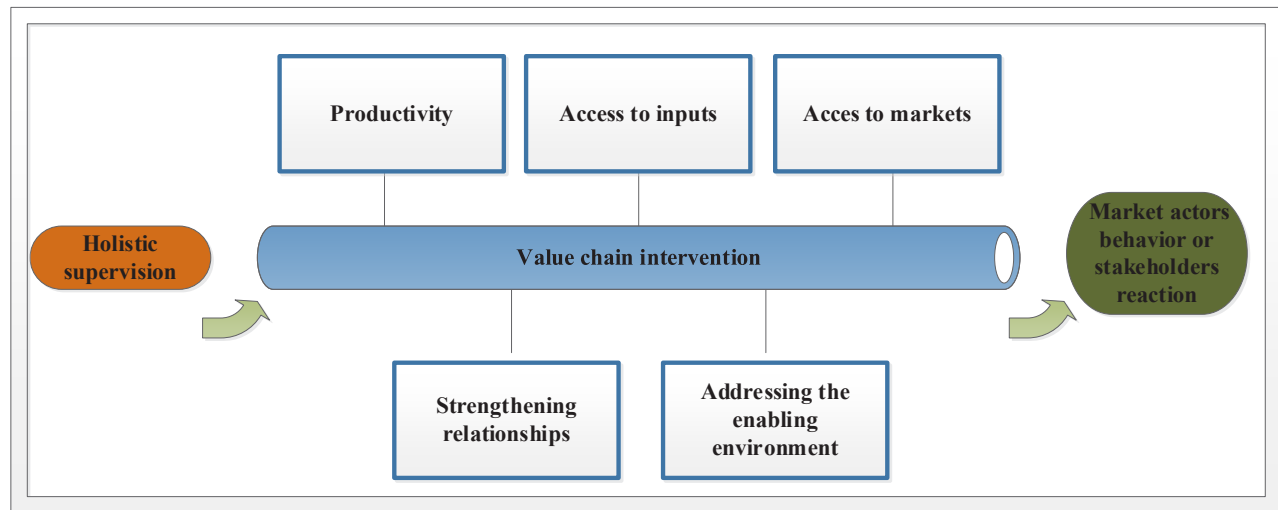

Source: Author, processed, year 2021

Fig. 2. Value chain interventions mapping

\subsection{Selecting alternative policies}

Furthermore, selecting alternative policies in seed circulation of the national forest sector are critical stage, especially when it considers increasing specific cooperation pattern based on an ecological, economic and social perspective. A cluster perspective can be constructive for showing the complex structure and interactions between the different market actors or stakeholders and the chain of production and value-adding [10]. Applying the cluster concept can also be highly relevant for increasing the competitiveness of the market opportunities and supporting the forest cover's sustainable development. Due to the complexity of cluster management, a large number and a wide range of different types of relevant local-seed variety can influence the policy arena. Figure 3 shows the framework of cluster policy development, and their cooperation patterns become critical for successful cluster management based on local-seed variety. Large proportions of creative class in the regional economy can lead to economic development [11]. A large number of different types of interactions happening in the same place increase the likelihood of innovations [12].

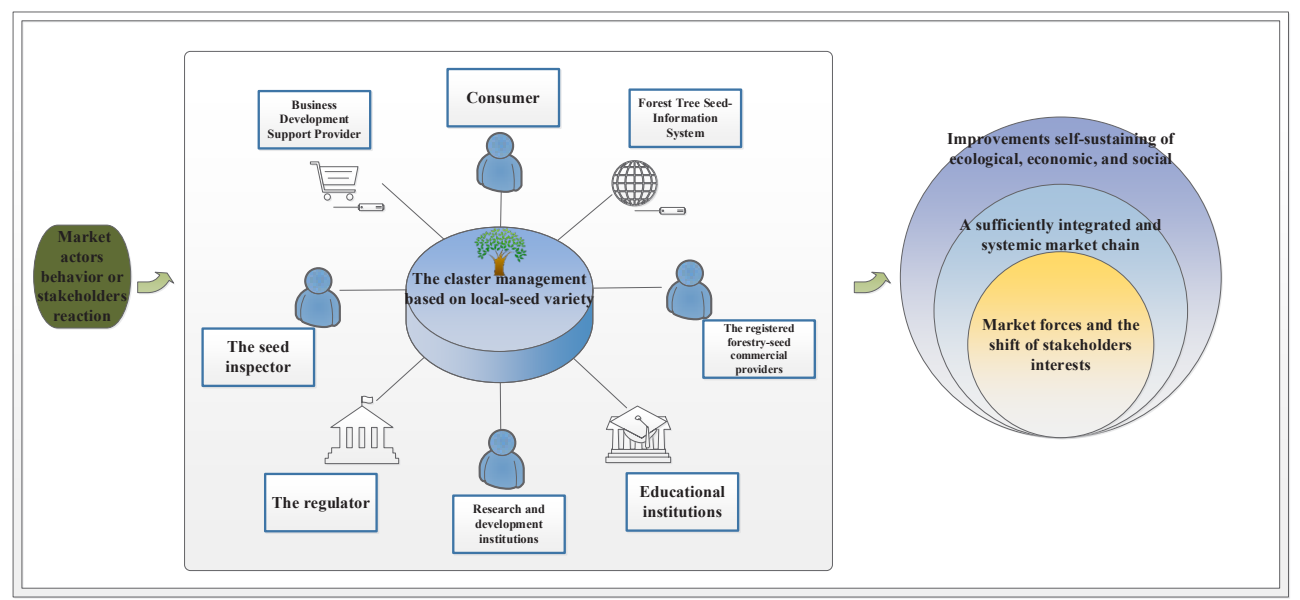

Source: Author, processed, year 2021

Fig. 3. The framework of cluster policy development 


\subsection{Establishing procedures}

Figure 3 shows the coordination of forestry seed commercial provider's activities. It lacks informational and technical support, marketing and sales, qualification of seed-source, public relations, and lobbying. The permanent nursery was unlimitedly considered as stakeholders although forestry seed commercial providers were also involved in business activities to some extent. The framework of the upscaling seed-circulation policies also has a political voice-oriented in a commercial-administrative arrangement (Figure 5). It is in the form of recommendations for improving communication and cooperation within the demand creation to the central government. The main approaches for improving communication and cooperation behavior among the stakeholders are networking as well as cluster management policy and seed source development.

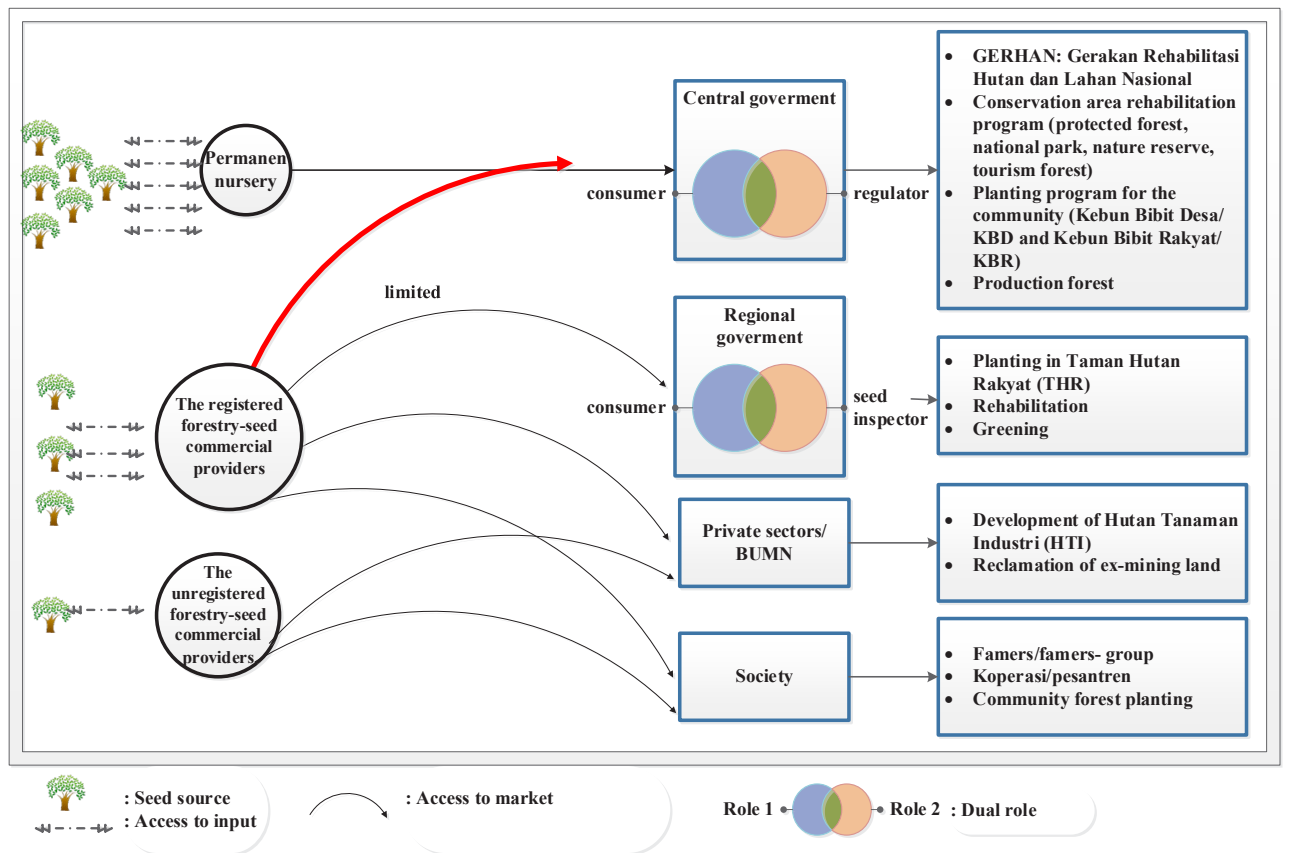

Source: Author, processed, year 2021

Fig. 4. The framework of seed-circulation: before intervention 

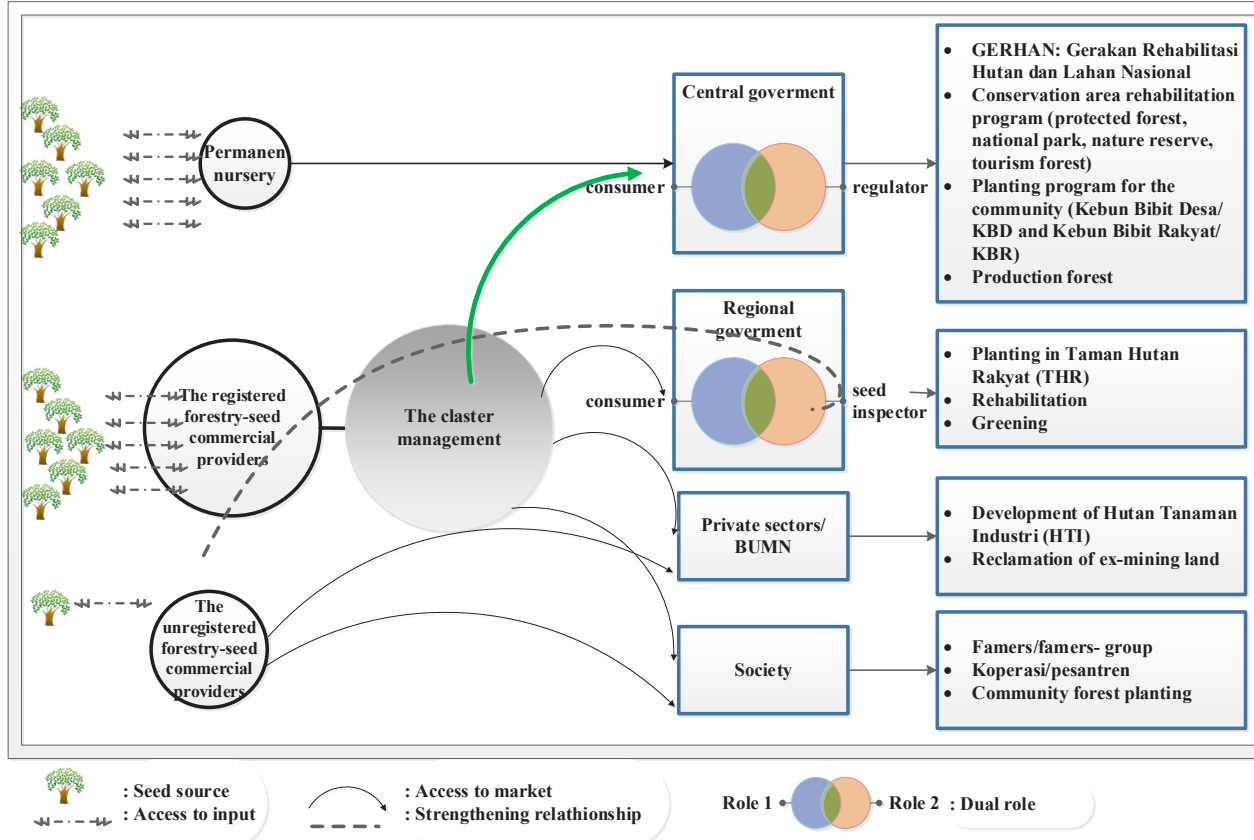

Source: Author, processed, year 2021

FiG. 5. The framework of the upscaling seed-circulation policies

\section{Conclusions and recommendation}

\subsection{Conclusions}

The approach and case study presented in this study can formulate the main problem in seed circulation policy. Evaluation of the forestry seed commercial providers sector is seed source development, seed variety coordination at permanent nurseries, law reinforcement, and regulator role strengthening. The value chain intervention is the competitiveness foundation for supporting the sustainable development of the forest. It is a sufficiently integrated and systemic policy agenda to improve ecological, economic, and social selfsustaining along the market chain. One of the most interesting solutions in the field of organized seed sectors is the cluster management. Selecting an alternative policy in the context of the cluster concept can provide an improved understanding of stakeholder structures and interactions. It can support cooperation between stakeholders. Based on these principles, the creation of the cluster management will determine the further improvement of procedures or requirements prescribed by ministerial forestry regulations. Established procedure in a commercial-administrative arrangement causes communication forces improvement and the shift of stakeholders' interests.

\subsection{Recommendation}

However, whereas the framework for seed-cluster management based on local-seed variety presented in this study contributes to an improved understanding of seed-circulation policy, further development, refinement, and case study testing of concepts and methods are 
needed. There will be a need to reflect the comprehensive concern of cluster policy model in regional economic systems. It will allow a differentiated approach to stimulate the further development of the living standard of market actors or economic agents.

The research leading to these results has received funding from the Pusat Unggulan Iptek (PUI) Programme from the Ministry of Research, Technology and Higher Education (RISTEKDIKTI).

\section{References}

1. BPS, Statistik kementerian lingkungan hidup dan kehutanan, source url: https://www.bps.go.id/indicator/60/588/1/luas-lahan-kritis-menurut-provinsi-dantingkat-kekritisan-lahan.html (2018)

2. KLHK, Keputusan Direktur Perbenihan Tanaman Hutan Nomor 71/PTH-4/2009 tentang pedoman perhitungan kebutuhan benih nasional, source url: https://www.persemaianpermanen.com/lib/peraturan.php?\# (2009)

3. KLHK, Rencana strategis Direktorat Jenderal Pengendalian DAS dan Hutan Lindung tahun 2020-2024, source url: https://www.menlhk.go.id/uploads/site/post/1610948544.pdf (2019)

4. PikiranRakyat.com, Penangkar bibit di Majalengka mengeluh, source url: https://www.pikiran-rakyat.com/ekonomi/pr-01247834/penangkar-bibit-di-majalengkamengeluh (2016)

5. West Java local government, Peraturan Gubernur Nomor 91 Tahun 2016 tentang tugas pokok, fungsi, rincian tugas unit dan tata kerja unit pelaksana teknis dinas di lingkungan dinas kehutanan Provinsi Jawa Barat, source url: https://jdih.jabarprov.go.id/page/info/produk/9078 (2016)

6. R.A. Likert, Technique for the measurement of attitudes. Archives of Psychology, 140 (1932)

7. KLHK, Peraturan Menteri Lingkungan Hidup Dan Kehutanan Republik Indonesia Nomor P.3/menlhk/setjen/kum.1/1/2020 tentang penyelenggaraan perbenihan tanaman hutan, source

url: http://jdih.menlhk.co.id/uploads/files/P_3_2020_PERBENIHAN_TH_menlhk_021220 20104811.pdf (2020)

8. K. McKague, M. Siddiquee, Value chain intervention strategies. In Making Markets More Inclusive (pp. 47-55). (Palgrave Macmillan, New York, 2014)

9. F. Falah, B. Nugroho, Jurnal Penelitian Hutan Tanaman, 7, 3 (2010)

10. M. Teder, P. Kaimre, Forest Policy and Economics, 89 (2018)

11. K. Stolarick, E. Currid-Halkett. Cities, 33 (2013)

12. M. Batty, Science 340.6139 (2013) 